\title{
CONFLICT OF LAWS: APPLICATION OF FOREIGN REMEDIES.
}

$\mathbb{I}_{\mathrm{T}}$ is ofTEN recited in conflict of laws cases that although courts will recognize foreign substantive rights, they: will not apply foreign. remedies. ${ }^{1}$ However, when remedies of the forum are not adequate to enforce foreign substantive rights, strict adherence to this rightstemedies dichotomy could defeat the purposes of recognition. In Phrantzes v. Argenti, ${ }^{2}$ an English court recognized a right to dowry. created by Greek law ${ }^{3}$ but held that the claim must be dismissed because under English law no adequate remedy was available torenforce the dowry right. ${ }^{4}$

Greek law requires a father to enter into a dowry contract when his daughter marries. If he fails to do so, a Greek court can determine the appropriate amount of dowry and specify the particular assets to be handed over: Factors to be considered are the father's wealth, the number of his children; and his social position relative to that of his son-in-law. Dowry need not be given, however, if a minor daughter marries without her father's consent or' if the court in its discretion finds that the father would endanger his own proper maintenance by giving dowry, that the fortune of the daughter is adequate without dowry, or that the daughter has committed such a "fault" as would justify disinheritance. In Phrantzes, a Greek national brought suit in an English court $^{5}$ to require her father, also a Greek national, to enter into a dowry contract. The court dismissed the action because English law provided

$\frac{1 .}{{ }^{1} \text { E.g., Atchison T. \& S. F. Ry. v. Spencer, 20.F.2d.7.14 (9th Cir. 1927); . Portwood }}$ v. Portwood, rog S.W.2d 515 (Tex. Civ. App. 1937); Strawn Mercantile Co. v. First Nat'l Bank, 279 S.W. 473 (Tex. Civ. App. 1925).

$\therefore$ [1960] 2 Weekly L.R. 521 (Q.B.), [1960] 1 All.E.R. 778. Reviewed in 9. INT'L \& COMP. E.Q. 508 (1960); 23 MODERN. L. Rev. 446 (1960). , $\therefore{ }^{3}$ The conflicts theory espoused by the court was the "foreign' created right" doctrine. See Loucks v. Standard Oil Co., 224 N.Y. 99, 120 N.E. 198 (1918) (Cardozo, J.).

[I960] 2 Weekly L.R. 521,529 (Q:B.), [x960] I All E.R: 778, 784 .

"Both father and daughter 'were residing in England at the time of the action. Greek law provided for extraterritorial enforcement of the right. Several American cases have refused even to consider the applicability of Greek law when considering a Greek dowry agreement. Christopoulos v. Contos; 4. F.2d 560 (E.D. Pa. 1925); Klimis v. Klimis, 158 Fla. 159,28 So. $2 \mathrm{~d}$ 112 (1946). See Ehrenzweig, Fragistas, \& Yiannopoulos, American-Greek Private Internationali LaW 58-59 (1957). 
no remedy by which one might be forced to enter into a conitract with a nonparty to the proceedings. ${ }^{6}$

The rule that courts will not apply foreign remedies appears to be firmly entrenched. ${ }^{7}$ The Restatement of the Conflict of Larws, 8 on which the court in the Phrantzes case relied, ${ }^{9}$ takes the position that a claim based on a foreign substantive right must be dismissed if the forum has no remedy or form of action comparable to that provided by the foreign law. ${ }^{10}$ American case law apparently supports the Restatement position. ${ }^{11}$ In the leading American case, Slater $v$. Mexican Nat'l R.R., ${ }^{12}$ suit was brought in Texas to recover damages for wrongful death arising out of an accident in Mexico. Mexican law provided for periodic payments in the nature of a pension, subject tô

${ }^{\circ}$ The decision noted here was on a preliminary question ordered by a master. The court proceeded on the assumption that the defendant was at all material times domiciled in Greece, and, thus, that Greek law governed the relationship. "It is [the law of the father's domicile] which will say . . . whether a daughter is legally entitled on her marriage to a dowry ... from her parents." WolfF, Private Internationai: LAW 390 (2d ed. 1950).

'E.g., Atchison T. \& S. F. Ry. v. Spencer, 20 F.2d 714 (9th Cir. 1927); Portwood v. Portwood, rog S.W.zd 515 (Tex. Civ. App. I937). See also, Restatement, ConFLICT OF LAWS $\$ 585$ (1934); DiceY, CONFLICT OF LaWS ro89 (7th ed. 1958).

${ }^{8}$ Restatement, Conflict of Laws $\$ \S 608-609$ (1934).

- [x960] z Weekly L.R. 521,530 (Q.B.), [1960] I All E.R. 778, 784. The only English case cited in Phrantzes in support of the RESTATEMENT \$§ 608-609, is Baschet v. London Illustrated Standard Co., [1900] I Ch. 73 (1899). In Baschet; however, the English court did grant a remedy; the case turned upon the provisions of the International Copyright Act and the Bern Convention. See generally 1 LADAS, The International Protection of Literary and ARtistic Property 605 (1938).

${ }^{10}$ 'No Form of Action Provided. If no form of action is provided by the law of a state for the enforcement of a particular foreign right, no action to enforce that right can be maintained in the state. Comment: a. The form of action is a matter of procedure. A court will not invent a new form of action, unknown to the law of the forum, in order to give a remedy on a foreign cause of action." RESTATEMENT; Conflict of Laws $\$ 608$ (1934). "Action wOUld Result in MORE OnERous Durry. If a judgment in an action provided by the law of the forum would impose on the defendant a more onerous duty than that imposed by the law of the state which created the right, or a substantially different duty, no action can be maintained." : Id. $\S 609$.

${ }^{11}$ See Weidman v. Weidman, 274 Mass. IIS, I74 N.E. 206 (I93I) (involved statute prohibiting suits between husband and wife); Golder v. Golder, 235 Mass. 26, 126 N.E. $3_{2} 82$ (1920) (dictum); Howard Undertaking Co. v. Fidelity "Life Ass'n, 59 S.W.2d 746 (Mo. Ct. App. 1933) (remedy of assignee determined by law of forum); Metzler v. Metzler, 8 N.J. Misc. 821, 151 Atl. 847 (1930) (no suit allowed on foreign judgment between husband and wife). These cases are the basis for $\S 608$ of the Restatement:" 'See ' 3 'BeAle; The Conflict of LAWs $\S 608.1$ nn.4 \& 5 ('ig35).

19194 U.S. $120\left(\mathrm{x}_{904}\right)$. 
various discretionary changes. Texas law provided for only a lump sum payment. The Supreme Court dismissed the claim because Texas had no remedy comparable to that available in Mexico. ${ }^{13}$ In a representative New York case, Mertz v. Mertz, ${ }^{14}$ a wife sought damages against her husband for injuries negligently inflicted on her while they were in Connecticut. Connecticut law permitted a wife to recover against her husband for personal injuries, but New York law did not. ${ }^{15}$ The court treated New York's prohibition of inter-spousal suits as a procedural incapacity and held, therefore, that New York law governed the remedy.

Although these cases are typical of those which espouse the Restatement position, ${ }^{16}$ they do not require the broad generalization that if the remedies of the forum are inadequate to enforce a foreign substantive right, a claim must inevitably be dismissed. In both Slater and Mertz, additional reasons were assigned for not applying the foreign remedy. In Slater, the defendant was doing business in Mexico $^{17}$ and, thus, was amenable to suit in nearby Mexican courts..$^{18}$ Presumably, Mexican courts could have reached a result more in harmony with the complex and discretionary Mexican right. It was not. inappropriate in these circumstances to require that the plaintiff resort to a foreign court. ${ }^{19}$ In Mertz, the forum not only lacked an

${ }^{13}$ Mr. Chief Justice Fuller, dissenting, said that the claim should not be dismissed. He reasoned that the Texas remedy was adequate to justly enforce the parties' rights. The majority opinion in the Slater case was the chief basis for $§ 609$ of the Restatement. See 3 Beale, The Conflict of LaWs § 609.1 (1935).

${ }^{24} 271$ N.Y. 466,3 N.E.2d 597 (1936).

${ }^{15}$ In conflicts cases a "state" is a unit of territory having a single body of law. Thus, conflicts rules applicable between nations are generally applicable betwcen the several states of the United States. See 1 BEALE, THE CONFLICT of LAWs $\S$ 2.5 (1935). In many cases, however, this promiscuous treatment is unjustified. See I Ehrenzweig, Conflict of Laws § 6 (1959); Ehrenzweig, Fragistas, \& Yiannopoulos, American-Greek Private Internationai. LaW 56 (1957); Ehrenzweig, Interstate and International Conflicts Law: A Plea for Segregation, 4I MrNo. L. REV. $7 \times 7$ (1957). Because of the requirement of full faith and credit between sister states, the grounds for nonrecognition are broader in international cases. STUMBERG, Conflict OF LAWS $\times 30$ (2d ed. 195I).

${ }^{10}$ The cases on which $\S 608$ of the Restatement is based could have been decided on the basis of a contrary public policy of the forum. See cases cited note in supra.

${ }^{17}$ The Mexican National Railroad operated in both Mexico and the United States, and was therefore doing business in both places.

${ }^{18} \times 94$ U.S. $120, \times 29$ (1904).

${ }^{20}$ If the Slater case had been brought in equity, the court might have granted a remedy comparable to the Mexican remedy. See Goodrich, THE Conflict of LAWs $30 \mathrm{n.77}$ (3d ed. 1949). See also, note 30 infra. 
adequate remedy, ${ }^{20}$ but the remedy sought was contrary to its public policy. ${ }^{21}$ It is well recognized that the forum need not apply foreign law that is against its public policy. ${ }^{22}$ This ground alone was adequate to explain the court's decision. Similarly, in Phrantzes, at least two grounds other than the rights-remedies distinction could have been the basis of the decision. English courts will enforce foreign judgments only if they are final money judgments. ${ }^{23}$ Therefore, even if a Greek court had ordered the father to enter into a dowry contract, that judgment would not have been enforced in England. Arguably, then, the English court was justified in refusing to enforce a foreign created right that would not have been enforcable even if it had been reduced to judgment in the foreign country by a court properly exercising jurisdiction in accordance with English conflict of law rules. Although this first ground was not adverted to by the court, it expressly relied on the second ground. ${ }^{24}$ It found that enforcement of the Greek right involved too much discretion. ${ }^{25}$ Thus, as in Slater and Mertz, the court, in refusing to apply foreign remedies, adverted to a more narrow basis than the broad rights-remedies distinction.

Although courts have refused to apply foreign remedies, they have applied other foreign procedural laws. ${ }^{26}$ In Precourt $v$. Driscoll, ${ }^{27}$ the New Hampshire Supreme Court held that a Vermont rule on the burden of showing due care, although procedural, could be applied in

\footnotetext{
${ }^{20}$ By taking a more restricted view of public policy, the dissent in the Mertz case reached the conclusion that the foreign right should be enforced.

${ }_{22} 27$ N.Y. 466, 472, 3 N.E.2d 597, 599 (×936).

${ }^{22}$ E.g., Ferneau v. Armour \& Co., 303 S.W.2d r61 (Mo. Ct. App. 1957); Associates Discount Corp. v. McKinney, 230 N.C. 727,55 S.E.2d. 513 (1949). See also, Restatement, Conflict of LaWs $\$ 6$ I2 (1934).

${ }^{23}$ Harrop v. Harrop [19zo] 3 K.B. 386; Cheshire, Private InternationaI LAW 626-29 (5th ed. 1957); DICEY, CONFLICT OF LAWS 1033-34 (7th ed. 1958); Wolff, Private INTernational LaW 258 (1945); Decisions, 9 INT'L \& Comp. L.Q. $508,510(x 960)$.

24 [1960] 2 Weekly L.R. 52I, 529 (Q.B.), [1960] I All E.R. 778, 784.

25 "The exercise of a discretion, even though it be a judicial discretion, necessarily involves some personal contribution from the court to the solution of the problem, and where that personal contribution is one which has to come from a particular tribunal and no other ... it appears to me it is not a contribution which any other court has any right or jurisdiction to make." Kornatzki v. Oppenheimer, [I937] 4 All E.R. 133, I38 (Ch.).

${ }^{10}$ See Lykes Bros. S.S. Co. v. Esteves, 89 F.2d 528 (5th Cir. 1937); Thomas Iron Co. v. Ensign-Bickford Co., 131 Conn. 665, 42 A.2d 145 (x945); Dorr Cattle Co. v. Des Moines Nat'l Bank, I27 Iowa 153, 98 N.W. 9x8 (1904) (dictum).

${ }^{27} 85$ N.H. 280, 157 Atl. 525 (193I).
} 
New Hampshire. In observing that the application of the foreign procedure was essential to the preservation of the foreign right, the court said: $:^{28}$

If the local remedy results in destroying or altering the foreign cause of action, the ends of comity are ... defeated .... [A way to avoid such. a result $].$. is to make an exception to the rule applying the local law when the foreign remedy is so inseparable from the cauise of action that it must be enforced to preserve the integrity and character of the cause and when such remedy is practically available.

The court left no doubt ${ }^{29}$ that it was through comity that the foreign procedural rule was applied. ${ }^{30}$ Other cases, which in fact adopt the philosophy of the Precourt decision, have neatly sidestepped the substantive-procedural dichotomy by classifying borderline rights as substantive. $^{31}$ For example, a statute of limitations may be characterized as either substantive or procedural, depending upon whether it affects the existence of the substantive right or merely bars the remedy. ${ }^{32}$

Generally, the substantive-procedural distinction is necessary to make an application of foreign law workable. It is impractical to require a court not only to ascertain and apply foreign substantive law but also to adopt all of the procedural rules and machinery of a foreign system

\footnotetext{
${ }^{28} I d$. at $283,{ }_{57}$ Atl. at 527 .

${ }^{30}$ "Authority on the point is scanty and its weight is possibly against the proposition. But it would seem that comity may properly recognize it [the procedural right] when the situation in a particular case warrants. The 'courtesy' of comity should not become discourtesy." Ibid.

${ }^{30}$ Probably the best theory with which to enforce a foreign right, when the forum has no remedy comparable to the foreign remedy, is that of applying the foreign remedy. Equity, however, has broad general powers to create new remedies if necessary. For possible difficulties involved in" the equity approach, see Slater v. Mexican Nat'l R.R., r94 U.S. 120, 124 (rgo4) (respondent's brief).

${ }^{31}$ See Tyson v. Scartine, 49 Del. 442, Ir8 A.2d 795 (1955). Compare Auffenberg Lincoln-Mercury v. Wallace, 3 is S.W.2d 528 (Mo. Ct. App. 1958), with General Motors Acceptance Corp. v. Crawford, 3 I N.E.2d 689 (Ohio Ct. App.), appeal dismissed, 135 Ohio St. 569, 21 N.E.2d 677 (1939). See generally 47 HARv. L. REv: 315 (1933).

${ }^{32}$ See Restatement, Conflict of Laws $\S 605$ (1934); 3 Beale, The Conflict.

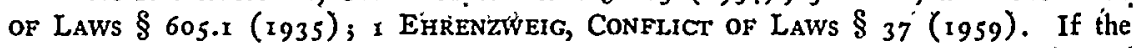
limitation is created by the same statute which creates the substantive right, it is usually'

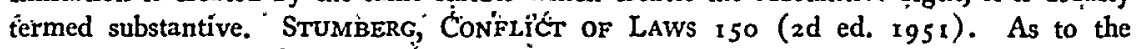
effect of the full faith and credit cfause on statutes of limitation, sce Comment, 4 DUKE: Bar J. 71 (ig $5 \dot{4})$. See generally Morineau, Rights and Remedies, 8 Am.'J. Comp. L. 263 ( 2959 ).
} 
Although foreign remedies and procedures usually will not be applied, this does not mean that they should never be applied. ${ }^{33}$ Foreign rights should be enforced whenever possible ${ }^{34}$ in order that no right go unenforced because of mere accident of judicial boundaries. ${ }^{35}$ When substantive rights are so bound up in a foreign remedy that refusal to adopt the remedy would substantially deprive parties of their rights, the necessity of vindicating the foreign rights outweighs the practical difficulties involved in applying the foreign remedy. ${ }^{36}$ Where necessary, foreign remedies and procedures can be proved by expert witnesses as readily as can foreign substantive rights. Even if a foreign remedy is not treated precisely as it would be by a foreign court, it would seem preferable to adopt the foreign remedy rather than to grant no relief at all. This is especially true if the plaintiff does not have recourse to another court. ${ }^{37}$ In such a situation, to say that the right is

${ }^{33}$ Indeed, in United States cases, full faith and credit, which usually requires recognition of a sister state judgment, may require application of the foreign remedy. Compare Bradford Elec. Co. v. Clapper, 286 U.S. I45 (1932), which held that a statutory remedy must be given full faith and credit if asserted defensively. But see, Alaska Packers Ass'n v. Industrial Comm'n, 294 U.S. 532 (x935); Weidman v. Weidman, 274 Mass. I 8 , 174 N.E. 206 (193 I).

34 "There is a growing conviction that only exceptional circumstances should lead one of the states to refuse to enforce a right acquired in another." Loucks v. Standard Oil Co., 224 N.Y. 99, I13, I20 N.E. x98, 202 (19x8) (Cardozo, J.).

${ }^{35}$ "An exception should be made to the general rule that remedial rights are determined by local law when the foreign remedy is so inseparable from the cause of action that it must be enforced to preserve the integrity and character of the cause and when such a remedy is practically available." II AM. Jur. Conflict of Laws \$ I86 (1937). "As an exception to the general rule that the lex fori controls the remedy and procedure it has been held that, in the absence of intervening domestic interests, the lex loci will govern the remedy when the foreign remedy. is so inseparable from the cause of action that it must be enforced to preserve the integrity and character of the cause and when such remedy is practically available." ${ }_{5}$ C.J.S. Conflict of Lowes $\$ 22$ (1939). "If the rule is one whose operative effect is likely to affect materially the result, and its choice as controlling is not apt to disturb substantially the efficient operation of the judicial machinery at the forum the foreign rather than local law should, it is believed, be applied without regard to classification as substantive or procedural for other purposes." STUMBERG, Conflict of LAws ío (2d ed. 195i).

${ }^{30}$ Although this rationale seems applicable to foreign equitable rights, they are more often discretionary or contrary to the forum's policy, and need not be applied if that is the case. See Stumberg, Conflict of LaWs r28-3o (2d ed. 195 I). But see Reese, Full Faith and Credit to Foreign Equity Decrees, 42 IoWA L. REv. I83, 191 (r957).

${ }^{37}$ In the Phrantzes case the plaintiff could possibly recover by suing her father for money damages in a Greek court. "The settled [Greek] judicial practice [extends] ... jurisdiction .... to all defendants of Greek nationality . . . ". EHrENzWEIG, Fragistas, \& Yiannopoulos, American-Greek Private International Law 30 
recognized, but not the remedy, is but judicial obscuration, ${ }^{38}$ for, " $a$ right without any remedy is a meaningless scholasticism."30

When a foreign substantive right cannot be adequately enforced except by applying a foreign remedy or procedure, then, absent countervailing factors, ${ }^{40}$ the essential foreign remedy or procedure should be applied. It is to the reciprocal advantage of the courts of all nations to enforce foreign rights as far as practicable. To this end, broad recognition of substantive rights should not be defeated by indiscriminate application of the rights-remedies distinction.

(1957). She might then have been able to enforce the Greek judginent in England. "In actions in personam there are five cases in which the Courts of this country [England] will enforce a foreign judgment: $(x)$ Where the defendant is a subject of the foreign country in which the judgment has been obtained . ..." Emanuel v. Symon [1908] I K.B. 302, 309 (C.A. 1907) (dictum).

${ }^{38}$ See Cook, "Substance" and "Procedure" in the Conflict of Lasws, 42 YALE L.J. 333 (1933); Ehrenzweig, The Lex Fori-Basic Rule in the Conflict of Laws, 58 MicH. L. REv. 637 ( 1960 ). "When Chief Judge Lehmann [in the Mertw case] refused to apply Connecticut law over the forum's prohibition of inter-spousal suits, he proved too much when he claimed that 'no other state can, outside its own territorial limits ... provide by its law a remedy available in our courts which our law denies to other suitors.' Of course, Connecticut cannot, in the New York court, 'provide' a new remedy. But New York may, under Connecticut law, grant a remedy for Connecticut accidents. That it may choose not to do so in order not to discriminate against those suing on New York accidents is a question to be settled by reformulating the New York conflicts rule so as to extend the New York disability to foreign accidents. Only such unworkable 'rules' as that of the Restatement which purports to require ubiquitous application of the lex loci have compelled such unworkable exceptions as that purporting to require general application of the lex fori to all 'remedies.' Nothing less will do but a rethinking of those conflicts rules as exceptions from the lex fori." Id. at 677-78. (Footnotes omitted.) For an evaluation of the Restatement, see Lorenzen \& Heilman, The Restatement of the Conflict of Larws, 83 U. PA. L. REv. 555. (1935). See generally Salonga, Conflict of Laws: A Critical Survey of Doctrines and Practices and the Case for a Policy Oriented Approach, 25 PHIL. L.J. $50 \mathrm{I}$ (1950).

${ }^{30}$ Wood \& Selick v. Compagnie Generale Transatlantique, 43 F.2d 94r, 943 (2d Cir. 1930) (L. Hand, J.).

${ }^{30}$ Strong public policy of the forum against a particular foreign remedy, or practical difficulties in adopting it, might prevent recognition of a foreign remedy. 